\title{
The Importance of Geoheritage and Geo Top of the Charts in Environmental Studies
}

\author{
Ingrida Kepalaitè \\ Utena University of Applied Sciences, Faculty of Business and Technologies
}

\begin{abstract}
. scientifically the following categories are excluded: biodiversity, geoheritage, geodiversity, geo tops, nature objects and others. They are important from the scientific, aesthetic, tourism, cultural points of view. The aim of environment sciences has to be to analyse the categories exhaustively and to determine the conditions of protection.
\end{abstract}

Keywords: geoheritage, geodiversity, geo top, geosites.

\section{INTRODUCTION}

Quite often we read, hear and talk about the importance of saving biodiversity, about how environment pollution harms biodiversity, about how the growth of population requires growing more food sources and in this way the habitat areas - the home of biodiversity - are decreasing. But we rarely talk about the destruction of geological and geomorphologic objects because of the same reasons, especially because of agricultural development, construction. The mechanic erosion destroys the hills, deteriorates the soil. Contaminated ground water fastens the karst phenomena. Mining industry, large building move the ground surface, cause landslides, sometimes even earthquakes. New cultural layers destroy the surface that often can not even be recorded by scientists to preserve at least the graphic view of territory for the future research. For some time the world's geologists and geographers are trying to carry out as many scientific ground surface researches as possible, to present the results to the colleagues scientists, to the public and to the governments of their countries. But too little attention is paid to these spheres in the system of environmental sciences.

\section{RESEARCH METHODS}

It is important to determine the priorities of research and protection. More than twenty years ago, scientists have made a distinction only one category - the geographical extremes. There are the largest, longest, deepest natural objects. Now scientists distinguish much more categories. For example geodiversity, geohertage, geosities and other. Firstly, we need to determine what the geodiversity is, what most important objects should be included into the geo tops and geoheritage lists and to determine the level of their protection.
"Geoheritage" is a generic but descriptive term applied to sites or areas of geologic features with significant scientific, educational, cultural, or aesthetic value. Scientifically and educationally significant geoheritage sites include those with textbook geologic features and landscapes, distinctive rock or mineral types, unique or unusual fossils, or other geologic characteristics that are significant to education and research. Culturally significant geoheritage sites are places where geologic features or landscapes played a role in cultural or historical events. Aesthetically significant geoheritage sites include landscapes that are visually appealing because of their geologic features or processes. Many geoheritage sites can be tourist destinations and provide local and regional economic benefits."(Geological Society of America). [1]

Geoheritage is similarly defined in the recommendations of Council of Europe (2004) - it is scientific, cultural, aesthetic, landscape, economic and generic value of natural geological objects that must be preserved to the future generations. Present experience shows that geoheritage can be used for recreation, educational tourism, education and training but the most important its value is scientific. [2]

Geoheritage sites (Geosites) serve the public interest. Such sites are critical to advancing knowledge about natural hazards, groundwater supply, soil processes, climate and environmental changes, evolution of life, mineral and energy supplies, and other aspects of the nature and history of Earth. Such sites have high potential for scientific studies, use as outdoor classrooms, enhancing public understanding of science, recreational use, and economic support to local communities. Geoheritage sites can be small but scientifically significant sites. Geoheritage sites can also be extensive areas with international recognition. Large or small, and regardless of ownership, many are 
vulnerable to urbanization, infrastructure development, agriculture, over-use, or erosion. Conservation strategies appropriate to the type of site and nature of ownership are important to protect geoheritage sites from loss and maintain them for the long - term public interest. (Geological Society of America). [1]

World Heritage areas are also widely representative of geological and geomorphological phenomena, including:

- $\quad$ arid landforms;

- $\quad$ caves and karst;

- $\quad$ coasts, reefs and islands;

- $\quad$ ice fields and glaciers;

- $\quad$ fluvial, lacustrine and estuarine systems;

- mountain regions;

- $\quad$ tectonic, structural and stratigraphic features;

- volcanoes.

There are many geological sites around the world that are of international importance and we have a responsibility to conserve this geological heritage. [3]

\section{RESULTS AND DISCUSSION}

While analysing and preserving biodiversity, geodiversity can not be forgotten because it is the guarantee of the habitats stability for the all living organisms and their living territory. Only if the geodiversity is large, it is possible to distinguish unique and reference objects of geoheritage.

Geodiversity can be described as the variety of elements of geology — the rocks, minerals, fossils and soils - and the natural landforms and processes that shape them throughout geological time. Best known are those rare and exceptional occurrences such as dinosaur footprints or mammoth tusks, but there are many more less exceptional, but equally important, pieces of the geological jigsaw puzzle. When pieced together, these give an insight into past climates, earlier environments and life on earth. Geodiversity also recognises the link between people, landscape and their culture. The recognition of the concept of geodiversity represents an opportunity for the geological sciences to raise their profile, and raise awareness of the importance of abiotic (physical rather than biological) parts of ecosystems. Geodiversity is the process of recognising and assessing the value of geological features, collections, sites, monuments, artworks, and landscapes and the application of practices for their care, maintenance and management for the long-term benefit of all. [3]

Geodiversity is extremely important. It describes the diversity within abiotic nature and gives it a name with which people can relate to the idea that it is important. Not only the geology but the records of the geomorphological processes that have created the landscape we see today on top of which the archaeology produced by our ancestors has barely scraped the surface. Without this diversity we would not be able to live on this planet. It describes the beginning of the Earth and life on the planet; the massive processes that have formed our continents and oceans; the minerals, rocks and fossils that hold out mineral wealth in the form of ore and fossil fuel resources; the climates the planet endures many of which we have learned to thrive in such as rivers, coastal environments, glaciation, deserts and finally the record of continual processes like weathering and formation of soils. [4]

An area of geodiversity encompasses:

- the interactive relationships between geology and other interests;

- sites or features where representative examples of the areas of geological deposits and features can be seen;

- the historical legacy of geological research within the area;

- sites and features currently used in interpreting earth science;

- the location and nature of past and present mineral workings;

- the influence of geology in shaping the built and man-made environment;

- materials collections and records, published literature and maps.

All geological features are potentially vulnerable. In addition to obvious threats posed by inappropriate site development and the infilling of quarries, geological sites are also threatened by the encroachment of vegetation, natural weathering and general deterioration, which with time, may damage or obliterate important geological features. [3]

At the global level a number of conservation programmes now recognise, or are beginning to recognise, that geodiversity is an important element in our natural heritage, must be managed effectively if we are to realistically manage biodiversity, and is a potentially important component of sustainable development strategies, particularly in the developing world.

Global programmes include the World Heritage Convention, the Global Geopark Network supported by UNESCO and the Convention on Biodiversity. These provide the basis for international recognition of natural heritage management, but draw upon local and regional actions to make them a reality.

Many global programmes can only be effective if they recognise the need for close involvement by local communities in heritage management programmes. Local community involvement can only happen if the people who live and work in an area understand and value the heritage with which they live and for which they have a responsibility. [3]

So, it is important for the scientists, the governments, the media, the education to disseminate the most comprehensive information about the natural 
objects in the people's living environment that are significant from the scientific, aesthetic and tourism point of views. It goes without saying that the private property has to be respected and if the individuals do not want to have tourist attraction object in their plot, they have a right not to let the tourist in but the scientific researches have to be admitted as public interest and must be allowed. The scientists and the government should arise people's feeling of pride and encourage them to preserve the protected natural object. Some of natural objects were considered sacred pagan times. Part of the springs so far used for food and health promotion. Some of Geo top describe in legends and mythological story. Following these Geo top research showed that the legend reminds reality. Environmental sciences must be encouraged and their research spheres must be extended as much as possible. All the possible natural objects - living and non-living - must be explored. Having set the unique natural objects, they must be explored as comprehensively as possible, described and all the possible preservation options must be identified.

These labels and boundaries provide convenient areas to deal and work with, but geodiversity can and should be recognised beyond these protected area boundaries. Concepts and techniques can be applied at local, regional and national scales and geodiversity management can be successfully carried out to effectively promote geodiversity management. In many countries worldwide, geodiversity and geoconservation is being recognised for its value and importance. [3]

The Global Geopark Network (GGN) supported by UNESCO was established in 2004 to conserve Earth's geological heritage, as well as to promote the sustainable research and development by the concerned communities. The GGN membership is formed by national geological parks, or geoparks local areas focused on the protection of geological features and heritage.

The first members to the GGN were announced during the first International Conference on Geoparks in 2004. To date (January 2014) 100 geoparks from 30 countries are officially part of the GGN family. The European Geoparks Network (EGN), established in 2000, now consists of 49 Geoparks from 19 European Countries. Working together, the members co-operate to promote the protection of their geological heritage and to use that heritage to promote sustainable economic development in their respective regions. Of the 936 sites inscribed on the World Heritage List, 725 are cultural, 183 are natural and 28 are mixed sites. Only 20 are inscribed primarily because of their geological interest. [3]

In Lithuania UNESCO mostly protects the cultural objects. The Curonian Spit (Kuršių Nerija) is natural object partly protected by UNESCO. However, the most important international object to environmental sciences and all the geo sciences is Struves (Struvès) geodetic arch, the information about it is not spread widely.

One of the largest and most impressive attempt to analyse and determine the size and form of the Earth was the triangulation chain, made in 1816-1852. The Earth meridian's arch, which almost coincides with the edge of West and East Europe, stretched from the mouth of the Danube by the Black Sea to the Fuglenes (Norway) on the coast of the Arctic Ocean, i.e. from $45^{\circ} 20^{\prime}$ to $70^{\circ} 40^{\prime}$ of North Latitude. It crosses a few current states: Norway, Sweden, Finland, Estonia, Latvia, Lithuania, Belorussia, Ukraine and Moldavia. To calculate the arch's length and position, the measured fragments of triangulation nets in the above mentioned countries were used. When they were joined, the chain of $2820 \mathrm{~km}$ was obtained. The geographic latitudes difference between the edge points of this chain was $25^{\circ} 20^{\prime}$. At that time it was the most accurately measured and the longest arch of the meridian, its measurements results for entirely century were used to calculate and to specify the parameters of the Earth ellipsoid. [5]

The results of F.G.W.Struve's work were included in all the Earth ellipsoid parameters' calculations later made on the basis of the triangulation. This arch of the Earth meridian calculations has a huge scientific and cultural value. That is the reason why Finland Land Service and Finland Geodetic Institute in 1993 offered to include Struve (Struves) geodetic arch into the UNESCO World Heritage List and to perpetuate the most important geodetic points of the meridian arch as the UNESCO World Heritage object.

The National Land Service by the Ministry of Agriculture and Vilnius Gediminas technical university's Geodetic Institute chose and offered to perpetuate 3 geodetic points of Struve (Struvès) meridian arch out of 18 in Lithuanian territory - in Meskonys (authentic used form Meschkanzi), in Paliepiukai (authentic used form Beresnaki) and in Gireisiai (authentic used form Karischki) (now they are points of national geodetic net). [5]

The experience in the sphere of international cooperation geological heritage (e.g. in the association of Europe geological heritage) preservation and in other spheres allows to state that Lithuania's geological peculiarity is the continental glaciers and warm periods change history that is preserved in the geological layers and the forms of relief. This history covers all the period of quaternary from the oldest iceage to the retreat of the latest glacier. Such quaternary history, full of geological witnesses, can not be found in any of the neighbouring or northern countries. The other important aspect - is the history of the last iceage, palaeogeography, the diversity of all the classical forms left in the relief of our region. Besides, the relief also underwent the ice-age processes. [2] 
Geoheritage - is the remembrance of the Earth that must be saved to the new generations for Earth knowledge, scientific research that is constantly improving. It will never be too much of taking care of natural values, including geoheritage. It is a wide range of activities including the heritage value increasing, cleaning, public education and spread of information. There are 286 geological objects protected by state or municipalities in Lithuania. Beside the state protected geoheritage objects, there is one more geoheritage category - geo tops. They are scientifically and educationally (unique and reference) important geological, geomorphologic, hydrogeological objects and their groups - forms of relief, outcrop, boulders and their accumulations, high yield or increased mineralization ground water springheads, excavations, exposures and others. Very often they have huge aesthetic, tourist, archaeological, historical and cultural value. Most of them already have the status of nature heritage objects, the others are potentially claimed to be protected by the state. Part of the geo tops are in the private property or formed by human. [6]

For 20 years - since 1995 - geo tops are analysed and registered by Lithuania Geology Service by the Ministry of Environment. They are registered in the Geo tops subsystem of the State geology informative system. In this subsystem it is possible now to find information about 597 geological, geomorphologic, hydro geological and hydrographical natural heritage objects. They include 138 springs, 97 outcrop, 2 escarpment, 13 ravines, 54 huge hills, 15 grottos and suphosic cirques, 13 dunes, 1 cave, 12 eskers, 19 rocks, 175 boulders and 10 their exposures, 6 islands and peninsulas, 10 walls in the quarries, 11 sinkholes, 9 springy meadows, 12 continental dunes.

Geo tops are determined by carrying out state geological mapping, special scientific research, getting information from research organisations, individual nature explorers and promoters, and the directions of protected territories. [7]
Every state (municipality) has to „collect“ (register) its explored geocollection made up from geodiversity, geoheritage, geo tops and other reference and unique natural objects. This list will enable to know the available objects, research, protect them and be proud of them.

\section{CONCLUSION}

1. Geosites are analysed, the geo tops and geoheritage objects are distinguished, their scientific, aesthetic, tourism value is determined, the governments are offered to determine the mode of their preservation.

2. The Global Geopark Network supported by UNESCO and UNESCO protect the unique geoheritage objects and geoparks or geosites.

3. The state has to register its explored geocollection.

\section{REFERENCES}

[1] W. Rose, "What is Geohertage?," [Online]. Available: http://www.geo.mtu.edu/KeweenawGeoheritage/KeweenawG eoheritage/What.html [Accessed: Feb. 12, 2015].

[2] „Geological heritage - the direction to a better cognitive and understanding of the value," [Online]. Available: http://geografija.lt/2010/10/geologinis-paveldas$\%$ E $\% 80 \% 93$-geresnio-pazinimo-ir-vertes-supratimo-linkme/ [Accessed: Feb. 16, 2015].

[3] „Geodiversity,“ [Online]. Available: http://www.onegeology.org/extra/geodiversity/home.html [Accessed: Feb. 12, 2015].

[4] „Geodiversity and A Sense of 'Place',“ [Online]. Available: https:/geoheritagescience.wordpress.com/2012/06/30/geodive rsity-and-a-sense-of-place/ [Accessed: Feb. 12, 2015].

[5] Lithuanian National Commission for UNESCO, „Historical material of Struve Geodetic Arc," [Online]. Available: http://www.unesco.lt/kultura/pasaulio-paveldas/pasauliopaveldas-lietuvoje/struves-geodezinis-lankas/206-struvesgeodezinio-lanko-istorija [Accessed: Feb. 14, 2015].

[6] J. Satkūnas, „Geoheritage Day. Secrets of Sèliụ land geoheritage," (Geologinio paveldo diena. Sẻlių žemès geologinio paveldo paslaptys), 2014.

[7] „The list of the country's natural wealth - getting longer," [Online]. Available: http://alkas.lt/2015/02/10/saliesgamtos-turtu-sarasas-ilgeja/\#more-177106 [Accessed: Feb. 15, 2015]. 